\title{
Tendense in die studie van die kultuur van oraliteit: Implikasies vir die verstaan van die Matteusevangelie
}

Celia Nel \& A G van Aarde

Universiteit van Pretoria

\begin{abstract}
Tendencies in the study of orality: Implications for the understanding of the Gospel of Matthew

The 'formgeschichtliche' method has proved to be inadequate in its conclusions on the pre-literary phase of literary documents. The study of orality provides another means of investigating the oral stages of written documents. After investigating the features of an oral culture, this article points out that ancient writers communicated new information to their readers or listeners by using fomulas and themes already known to their audiences. The authors thus communicated something new to their audiences by using the already known. In this article it is argued that the Gospel of Matthew is suitable for illustrating the above principal, as the Matthean language is highly formulaic.
\end{abstract}

\section{INLEIDING EN HIPOTESE}

Hierdie studie is geinteresseerd in dit wat bekend staan as die kultuur van oraliteit. Hoewel die ondersoek na die uitwerking van die kultuur van oraliteit op die totstandkoming en inhoudgewing van die Nuwe Testament 'n relatiewe nuwe studieveld in die eksegetiese wetenskap is, behoort dit nie as 'n verassing te kom dat hierdie ondersoek wel by 'n bestaande studierigting in die Bybelwetenskap, te wete die Formgeschichte, aansluit nie. Tradisioneel gesien is die Formgeschichte as eksegetiese metode ontwerp om die pre-literêre fase van geskrewe dokumente te bestudeer en is bevind dat tradisies hulle onderskeie vorm kry vanweë die spesifieke Sitz-im-Leben. Die situasie (Sitz-imLeben) benodig dus 'n spesifieke vorm waarin 'n sekere inhoud gekommunikeer kan word. Tradisionele Formgeschichte is egter 'n ontoereikende ondersoek, aangesien dit bloot in 'n spekulasie oor die mondelinge fase eindig. Die mondelinge fase kon nie verder ondersoek word nie en dit het uiteindelik daartoe gelei dat die ondersoek op 'n

* Ingedien en aanvaar as deel van die vereistes vir die BD-graad (1994), Departement Nuwe Testament, Fakulteit Teologie (Afd A), Universiteit van Pretoria, onder leiding van prof dr A G van Aarde. 
dooie punt uitgeloop het. Die hipotese van die studie is dat die ondersoek na die kenmerke van die kultuur van oraliteit die moontlikheid bied om die doodloopstraat waarin die Formgeschichte beland het, te deurbreek. Dit bied die moontlikheid om vanuit 'n nuwe perspektief jarelange dispute weer onder oë te neem. Die resultate van die oraliteits-navorsing is egter nie alleen op grond van historiese oorwegings relevant vir die ondersoek na die oorspronge van literêre vorme in die Nuwe Testament nie, maar dit kan ook 'n belangrike bydrae lewer in die vraag na die effektiewe oordrag van die boodskap van die Bybel aan die miljoene ongeletterde mense wat hulle vandag steeds te midde van 'n kultuur van oraliteit bevind. Veral in die multikulturele situasie van Suid-Afrika, waar nie alle inwoners dieselfde mate van geletterdheid besit nie, kan dit van groot betekenis wees.

Afdeling twee van die studie het ten doel om die impasse waarin die Formgeschichte beland het, aan te dui. Daar sal verwys word na die bydraes van verskeie navorsers wat gepoog het om uit die doodloopstraat te kom. Soos reeds gesê, is dit die aanname vản die onderhawige studie dat die ondersoek na die kenmerke van die kultuur van oraliteit kan help om die leemtes in die navorsing in verband met die pre-literêre fase van dokumente in die Nuwe Testament te vul. In afdeling drie sal die hedendaagse tendense in die oraliteitsnavorsing aangedui word. Na aanleiding van die verkreë resultate sal die kommunikatiewe beginsel dat 'ou kennis' gebruik word om iets nuuts aan 'n gehoor oor te dra, in afdeling vier bespreek word. Hierdie beginsel open 'n nuwe moontlikheid vir die ondersoek na die formules wat in mondelinge kommunikasiesituasies gebruik is. In afdeling vyf sal die ondersoek gerig wees op die moontlikheid om die formulêre styl van die Matteusevangelie in die lig van die kultuur van oraliteit te bestudeer. Die vraag is of die Matteusevangelie as ' $n$ literêre teks met orale reste bestempel kan word. Indien dit wel die geval is, dan is die Matteusevangelie by uitstek geskik vir verdere navorsing in die lig van die studie van die kultuur van oraliteit. Die vraag wat hier ter sake is, is derhalwe 'n vraag na die neerslag van oraliteit in die Matteusevangelie.

\section{DIE FORMGESCHICHTE IN 'N DOODLOOPSTRAAT}

Die bedoeling van hierdie afdeling is om die impasse waarin die Formgeschichte beland het, uit te wys. Daar word egter nie in volledigheid op die Formgeschichte as sodanig ingegaan nie. In die afdeling sal aangetoon word op welke maniere gepoog is om die dilemma te deurbreek.

Die Formgeschichte het veral 'n opbloei in Duitsland na die Tweede Wêreldoorlog beleef. Die grondleggers van hierdie metode in die genoemde tydvak en hulle baanbrekerswerke was K L Schmidt, Rahmen der Geschichte Jesu (1919), M Dibelius, Die Formgeschichte des Evangeliums (1919) en R Bultmann, Geschichte der synoptischen Tradition (1921) (kyk Van Aarde 1984:22-23). 
Die formgeschichtliche metode gaan van die aanname uit dat 'n Bybelperikoop slegs korrek bestudeer kan word, indien 'n studie van die spesifieke literêre vorm en die spesifieke Sitz-im-Leben gedoen is (Van Aarde 1994:151). Voordat ek oorgaan om die verhouding tussen die Form en die Gattung te bespreek, is dit nodig om hierdie begrippe eers te omskryf. 'n Afgebakende eenheid met 'n unieke struktuur kan as 'n Form geïdentifiseer word. Verskillende afgebakende eenhede met soortgelyke strukture vorm deel van 'n groep wat as 'n Gattung bekend staan (kyk Richter, in Van Aarde 1994:154). Die vraag na die Sitz-im-Leben van die Gattung is dié na die funksie van die Gattung. Die Sitz-im-Leben is 'n produk van die sosiale gebruike en gewoontes wat gedurende 'n bepaalde tydperk en spesifieke situasie aan die orde van die dag was. Situasies benodig spesifieke literêre tipes om inligting interaktief te kommunikeer (kyk Koch, in Van Aarde 1994:159). Die formgeschichtliche metode is bedoel om die literêre vorm van 'n passasie te ondersoek. Die aanname ten grondslag van so 'n eksegetiese metode is die oortuiging dat die vorm van 'n perikoop iets van die preliterêre herkoms van die perikoop verraai. Hierdie manier van ondersoek het derhalwe ten doel om die ontstaan en geskiedenis van literêre eenhede te rekonstrueer en so die geskiedenis van die voor-literêre stadium van die eenhede aan te dui (Hahn 1985:2324).

Dibelius het die literêre vorm van 'n passasie na aanleiding van die inhoud daarvan geïdentifiseer (Van Aarde 1984:25). In die tradisionele Formgeschichte is hierdie inligting gebruik om aannames oor die Sitz-im-Leben van die bepaalde Form/Gattung te maak (vgl Dodd en Gunkel, in Van Aarde 1994:156). Dit het in latere navorsing aanleiding gegee tot spekulasie oor die Sitz-im-Leben (Vorster 1987:157). Bultmann, byvoorbeeld, gebruik nie die term Sitz-im-Leben as verwysend na 'n enkele historiese gebeurtenis nie, maar het die tipiese situasie in die lewe van die gemeente in die oog (Bultmann 1963:4; vgl Vorster 1987:157). Volgens Hahn (1985:30) het Bultmann hierdie situasie geklassifiseer as 'n situasie van strydgesprekke en onderriggeleenthede. Theissen (1991:5) sluit by Bultmann aan wanneer hy die term Sitz-im-Leben in verband met herhalende situasies gebruik. Hahn (1985:27) is van mening dat die Sitz-im-Leben van die evangelie as 'n situasie van prediking binne 'n sendingkonteks aangedui kan word. Bultmann (1963:5; vgl Vorster 1987:157) was egter terdeë bewus van die 'hermeneutiese sirkel' waarmee die Formgeschichte in die studie van die geskrifte van die Nuwe Testament werk. Hierdie sirkelredenasie neem die literêre vorme as uitgangspunt. Uit die literêre vorme word gevolgtrekkings gemaak oor die gemeenskapslewe waarbinne die vorme sou gefunksioneer het. Hahn $(1985: 48)$ sluit hierby aan deur daarop te wys dat die tradisies neerslag in sekere vorme gevind het. Die identifisering van die vorme open die deur vir afleidings oor die gebruik van die stof daarin in die situasies van die vroeë kerk. Vanuit die vorme kan inligting oor die Sitz- 
im-Leben verkry word. 'n Ondersoek na die stilistiese kenmerke van die vorme kan aandui uit watter tydperk die tradisies afkomstig is en so 'n bydrae lewer tot die vasstelling van die Sitz-im-Leben (Hahn 1985:239). Vanuit die identifisering van die gemeenskapslewe (Sitz-im-Leben) is die vorme - in 'n sirkelredenasie - weer verduidelik. Vir Bultmann (1963:5; vgl Vorster 1987:157) was die hermeneutiese sirkel 'n noodwendigheid in die studie van die Formgeschichte.

Dic impasse waarin die Formgeschichte beland het, is deels as gevolg van die spekulasie oor die mondelinge situasie. Dit loop weer uit op spekulasie oor die aard van entrsyds die literêre vorm en andersyds van die Sitz-im-Leben. Spekulasie (gegrond in die Gattung) oor die aard van die Sitz-im-Leben impliseer ook spekulasie (gegrond in die Sitz-im-Leben) oor die aard van die vorm. Spekulasie oor die wyse van mondelinge en literère kommunikasie hou voorts spekulasie in oor die vorme waarin gekommunikeer is, aangesien die wyse van kommunikasie die vorm waarin gekommunikeer is, beïnvloed. Verder word ook gespekuleer oor wat eerste was: Die vorm of die situasie? Sou die vorm spesiaal tot stand gekom het vir die doeleindes van die situasie of is daar bloot van 'n vorm (Gattung) gebruik gemaak wat alreeds in omloop was?

Dit is duidelik dat die mondelinge fase van literêre vorme vanweë hierdie impasse nie verder ondersoek kon word nie en dit het uiteindelik daartoe gelei dat die ondersoek op 'n dooie punt uitgeloop het.

Nuwe studies van die pre-literêre fase van tradisie-ocrleweringe poog egter om die doodloopstraat van die Formgeschichte te deurbreek. Ek gaan vervolgens 'n paar van dié nuwe insigte onder oë neem.

Werner Kelber was die eerste om 'n weg uit die dilemma aan te dui. Sy werk is beskryf as 'n 'breakthrough' (Farrel, in Botha 1990a:47). Hy onderskei tussen mondelinge en literêre kulture deur 'n ondersoek te loods na die verhouding tussen die geskrewe evangelie van Markus en die mondelinge tradisie van die Markusstof (Kelber 1980:20; vgl Botha 1990a:52). Dit lei tot 'n nuwe benadering in die ondersoek na onder andere die pre-literêre fase van literêre vorme. Met die literêre neerslag van die Jesus-tradisies het dit gebeur dat 'n '...literary mentality has taken control over and restructured oral mentality...' (Kelber 1980:35; vgl Botha 1990a:52). Kelber (vg1 Botha 1990a:52) is van mening dat Markus deur die gebruikmaking van die evangelievorm (literêr) die mondelinge tradisies oor Jesus wou verhinder. In sy boek The oral and written Gospel, poog hy om die evangelievorm as 'n '...counterform to an oral tradition...' (Botha 1990a:52) aan te dui. Botha (1990a:52) formuleer dit soos volg: '...to show that the written Gospel is a counterform to oral hermeneutics...' Kelber 
poog dus om die doodloopstraat van die tradisionele Formgeschichte te deurbreek wanneer hy die situasie van die mondelinge oorleweringe aandui as 'n situasie wat deur sekere mondelinge kenmerke, wat van 'n literêre situasie onderskei kan word, gekarakteriseer word. Volgens hom is 'n belangrike verskil tussen oraliteit en tekstualiteit '... orality's inability to narrate the death of a hero...' (Botha 1990a:53; vgl Kelber 1983:193). Die literêre neerslag van Markus was dus onderworpe aan wette wat verskil van dié wat in 'n mondelinge situasie aan die werk is (Kelber 1980:7). Sy 'interdisciplinary methodology' waarin hy onder andere ook van die antropologie en sosiologie gebruik maak, het hierdie potensiële deurbraak vir hom moontlik gemaak. Oor die feit of dit inderdaad 'n deurbraak was, kan gedebattee word. Ten minste kan die stelling gemaak word dat Kelber nuwe inligting oor die Sitz-im-Leben op die tafel geplaas het en dat dit nuwe deure vir die ondersoek na die pre-literêre fase van literêre vorme geopen het.

Gerd Theissen (1991) spreek die impasse van die Formgeschichte aan deur die gebruikmaking van 'n alternatiewe historiese metode wat hy 'n lokalkoloritische ondersoek noem. In die lig van die toenemende skeptisisme in die resultate van die Formgeschichte met betrekking tot mondelinge tradisies, poog hy om 'n teks met 'n spesifieke historiese situasie in verband te bring (Theissen 1991:2; vgl Horsley 1992:290). Theissen — volgens Horsley (1992:295; vgl Theissen 1991:2) — '... is seeking an alternative way of securing the pre-history of the synoptic gospels'. Hy volg in die voetspore van die histories-kritici deur die vraag te vra na die datering en die lokalisering van tekste. 'Where and when did the sources originate?' (Theissen 1991:2). Hierdeur wil hy die 'history of the synoptic tradition' aandui. Sy werkwyse gaan van die aanname uit dat 'n teks self 'clues' verskaf, dit wil sê daar is spesifieke verwysings, terme en gesegdes binne in die teks wat met spesifieke plekke of gebeure in Palestina in verband gebring kan word (vgl Horsley 1992:295). Theissen betwyfel dus nie die bestaan van die mondelinge tradisie-oorleweringe nie, maar probeer dit toelig deur die kulturele konteks daarvan in berekening te bring. Die verbande wat gelê kan word, noem Theissen (1991:7) 'lucky breaks', aangesien 'n skrale hoeveelheid rakpunte aangedui kan word. Hierdie 'lucky breaks' kan egter bydra om uiteindelik 'n geheelbeeld van die tradisiegeskiedenis van (in hierdie geval) die evangelies te gee. Sy metodologie neem egter nie die teks alleen as uitgangspunt nie, maar beide die teks en die sosiale en politieke konteks daarvan.

Op hierdie wyse wil hy opnuut 'n bydrae lewer tot die kennis oor en die rekonstruksie van die mondelinge situasie van tradisie-oorleweringe, want die historiese situasie waarmee Theissen die teks in verband wil bring, is in die eerste plek die spesifieke historiese situasie waarin die tradisie sy oorsprong gehad het en oorspronklik oorgelewer is. 
Soos die tradisionele Formgeschichte (kyk Lohr 1961:403) onderskei hy drie stadia:

* Die oudste tradisie het in Galilea vorm aangeneem.

* Die tweede fase van Jesus-tradisies het in 'n Joodse omgewing vorm aangeneem - 'n omgewing waarin die tradisies nie net in klein gesproke of literêre eenhede oorgelewer is nie, maar spesifiek in meer komplekse eenhede. Hy verbind die Caligula krisis (40 n C) met hierdie fase.

* Die evangelies self verteenwoordig die derde fase. Volgens Theissen (1991:291) is die evangelies geskryf as reaksie op die Joodse oorlog (66-74 n C).

Hy gebruik die konsep Sitz-im-Leben as 'n beskrywende term vir die 'ongoing social situations' (Theissen 1991:291). 'The Sitz-im-Leben of all the Gospel redactions is thus the "local community"' (Theissen 1991:292). Die evangelies het met ander woorde die tradisies wat uit ander sosiale milieu's gekom het, aangepas volgens die behoeftes van die 'local communities'. Die tradisionele Formgeschichte het nie spesifiek die 'cultural context' en die 'political history' van die tekste ondersoek nie (Theissen 1991:292). Dit is juis dié vrae wat Theissen ondersoek en probeer antwoord.

Dit is opvallend dat Theissen in sy boek Lokalkolorit und Zeitgeschichte in den Evangelien (1989) nie die tradisionele Formgeschichte in die geheel van die tafel vee nie. In die inleiding van sy werk neem hy die volgende uitgangspunte van die tradisionele Formgeschichte oor:

* Die hipotese van die bestaan van 'n mondelinge tradisie.

* Die hipotese van die bestaan van klein gesproke of literêre eenhede.

* Die moontlikheid om die mondelinge voorgeskiedenis van tekste te rekonstrueer.

Theissen wil deur sy ondersoek na die konkrete historiese situasies wat invloed op die oorlewering van die tradisies uitgeoefen het, 'n alternatiewe metode volg om die voorgeskiedenis van die sinoptiese evangelies te rekonstrueer. Hy noem sy metodologie 'a new beginning' (Theissen 1991:2). Die uiteinde van sy ondersoek lewer beslis 
'n aanvullende bydrae tot die tradisionele Formgeschichte. In 'n mate verdedig hy die tradisionele Formgeschichte wanneer hy poog om deur middel van 'n alternatiewe historiese metode die geskiedenis van die sinoptiese tradisie, wat begin by die mondelinge voorgeskiedenis en eindig met die literêre neerslag daarvan, na te vors (Theissen 1991:2; vgl Horsley 1992:290). Hy lewer veral 'n belangrike bydrae deur klem te lê op die invloed wat die sosiale en politieke situasie op die oorlewering van die sinoptiese tradisies uitgeoefen het. Hierdeur kom hy vorendag met perspektiewe wat nuwe insigte met betrekking tot die verstaan van die evangelies oplewer. Theissen gee egter nie aandag aan die literêre vorme waarin die tradisies oorgelewer is nie.

Volgens Horsley (1992:295) het Theissen nie werklik die invloed wat die sosiale en politieke konteks op die vorme van oordrag gehad het, uitgewys nie. Horsley (1992:295) stel dit soos volg: '... we must attempt to reconstruct the cultural and social forms through which the historical experience of those who produced the synoptic gospel traditions was mediated ....' Hierdie is 'n leemte by Theissen, omdat hy nie die kultuur van oraliteit in hierdie spesifieke situasies in ag neem nie.

Theissen se studie weerspieël wel 'n nuwe bewuswording in die huidige NuweTestamentiese navorsing: die Nuwe-Testamentiese dokumente is in die laat antieke tyd geproduseer. Hierdie bewuswording lei tot 'n groter belangstelling in die aard van die milieu waarin die dokumente geskryf is, aangesien kennis oor die konteks tot 'n beter verstaan van die dokumente bydra. Achtemeier (1990:3) dui aan dat daar veral een aspek van die konteks in die die Nuwe-Testamentiese navorsing verwaarloos is, en dit is die feit dat die kultuur van die laat Westerse antieke tyd 'n kultuur met 'n 'high residual orality' is. Achtemeier spesifiseer nie wat hy onder die term laat Westerse antieke tyd verstaan nie. In die lig van Harris (1991) se studies kan die tydperk moontlik deel vorm van die tyd vanaf die ontwikkeling van die Griekse alfabet tot ongeveer die vyfde eeu na Christus - 'n tydperk waarin daar grootliks mondeling gekommunikeer is. Mondelinge reste word bespeur in die geskrewe dokumente wat in hierdie milieu tot stand gekom het. Dit is daarom volgens Achtemeier (1990:4) belangrik om vas te stel hoe sulke dokumente hulle inhoud aan hulle beoogde lesers/hoorders gekommunikeer het.

Soos alreeds gemeld, was Kelber (1980) die eerste wat in ag geneem het dat die kulture van die reeds genoemde tydvak grootliks mondelinge kulture was. William Harris het die situasie van antieke geletterdheid vanaf die ontwikkeling van die Griekse alfabet tot ongeveer die vyfde eeu na Christus beskryf. Hierdie tydperk dek die preliterêre fase van die literêre dokumente waarvan die Nuwe Testament deel vorm. Die resultate van sy studie is derhalwe ook relevant vir die bestudering van die mondelinge voor-fase van die Nuwe Testamentiese geskrifte wat in 'n oorheersend mondelinge 
situasie tot stand gekom het. Volgens Harris (1989:7-8) kan die Grieks-Romeinse wêreld in dié genoemde tydvak grootliks as 'n mondelinge milieu beskryf word. In hierdie wêreld was $90 \%$ van alle mense ongeletterd. In gevalle waar daar wel van geletterdheid sprake was, kan tussen enersyds 'n 'scribal literacy' en andersyds 'n 'craftsman literacy' onderskei word. Harris verwys met 'scribal literacy' na 'n sekere sosiale groep wat geletterdheid met 'n spesifieke doel aangeleer het, byvoorbeeld om paleisrekords op te stel. Met die begrip 'craftsman literacy' het hy hoofsaaklik die 'skilled craftsman' in gedagte. Hierby kan ook genoem word dat minder vrouens as mans in hierdie milieu geletterd was. Die sosiale, religieuse en politieke elite wat 'n klein persentasie van die bevolking uitgemaak het, word wel deur Harris as geletterd getipeer. Geen massa geletterdheid het in die Grieks-Romeinse wêreld voorgekom nie en mondelinge kommunikasie het gevolglik 'n baie prominente rol vervul. Die meerderheid van die samelewing (geletterdes en ongeletterdes) het in die meeste gevalle glad nie van skrif gebruik gemaak nie. In sekere gevalle is daar wel van dis geskrewe woord deur middel van geletterde tussengangers gebruik gemaak. Dit is derhalwe duidelik dat die geskrewe woord nie die mondelinge situasie vervang het nie. Die geletterdes/elite het eerder briewe gedikteer as om dit self te skryf, boodskappe aangehoor in plaas daarvan om dit te lees, teater en opvoerings bygewoon in plaas daarvan om die dramas te lees. So is daar dus selfs onder die geletterdes aan die mondelinge prosedures vasgehou. Hier is met ander woorde sprake van 'n kuituur wat sigself tussen 'n 'suiwer' mondelinge kultuur en 'n 'suiwer' literêre kultuur bevind, meı 'n groter gewig op die mondelinge oordragsituasie. Daarom sê Harris (1989:327): 'But some of the marks of an oral culture always remain visible, most notably a widespread reliance on and a cultivation of the faculty of memory'.

Harris toon verder aan dat verskillende grade van geletterdheid op verskillende tye in die Grieks-Romeinse wêreld aanwesig was. Hy is byvoorbeeld van mening dat die geskrewe woord baie minder in die vyfde eeu en later as in die tydperk voor $250 \mathrm{na}$ Christus gebruik is. Volgens Harris vertoon die kultuur van oraliteit die volgende kenmerke:

* Goed ontwikkelde geheues was aan die orde van die dag, aangesien aaneenlopende tekste gememoriseer moes word. Hy formuleer dit soos volg: '... training of memory (was) ... the main aim of early communication ....' (Harris 1989:33). Dit het egter nie beteken dat tekste akkuraat op 'n verbatim wyse onthou is nie. Van geletterde orators is verwag om hulle toesprake spontaan uit die kop te lewer en daarvoor is die geheue en ander gespesialiseerde tegnieke ingespan. 
* Geletterdheid gee nie aanleiding tot skeptiese, kritiese, historiese, demokratiese denke nie, maar laat hierdie tipes denke wel sterk floreer, aangesien 'n situasie van geletterdheid 'n wye verspreiding van kennis en boeke impliseer.

* In 'n kultuur waar 'n hoë graad van geletterdheid onder die elite en hulle slawe en 'n lae voorkoms van geletterdheid onder die res van die bevolking aangetref is, moes ongeletterdes op die etrlikheid van geletterde tussengangers steun. Geletterdheid was dus 'n potensiële instrument tot magsmisbruik en leuens op sosiale, kulturele, politieke en godsdienstige vlakke (Harris 1989:335).

Ons het gesien dat Theissen se ondersoek wel toegespits is op die sosiale en die politieke konteks waarin antieke dokumente tot stand gekom het. In hierdie studie sal ek poog om 'n bydrae tot hierdie debat te maak deur die klem te laat val op die voorgeskiedenis van tekste en om veral van die insigte uit die oraliteitsnavorsing gebruik te maak. Oraliteitsnavorsing onderskei tussen mondelinge en literêre kulture. Ondersoeke na die kenmerke van 'n oorwegend mondelinge kommunikasiesituasie kan nuwe insigte bied in die wyse van die oordrag van mondelinge tradisies. Die wyse van kommunikasie beïnvloec' die vorme waarin gekommunikeer word. Besondere aandag moet derhalwe aan die wyse van kommunikasie in 'n mondelinge oordragsituasie gegee word. Nuwe insigte op hierdie gebied het die potensiaal om nuwe moontlikhede te open vir die interpretasie van tekste waarin die mondelinge kenmerke 'n literêre neerslag gevind het - met ander woorde, literêre tekste waarin mondelinge reste te bespeur is.

\section{HEDENDAAGSE TENDENSE IN DIE STUDIE VAN DIE KULTUUR VAN ORALITEIT}

In hierdie afdeling sal vervolgens 'n breë oorsig oor geselekteerde bronne, met oraliteit as onderwerp, gegee word. Die bedoeling is om die hedendaagse tendense in die navorsing van die kultuur van oraliteit aan te dui. In die ondersoek het duidelik geword dat daar verskillende vrae is wat in die navorsing aan die kultuur van oraliteit gestel kan word: vrae na die wyse van kommunikasie wat ook as linguïstiese vrae geklassifiseer kan word, vrae na die 'psigologiese' invloed van die tipe knmmunikasie en dan ook antropologiese vrae wat 'n sosiale beskrywing van die kultuur van oraliteit wil gee (kyk Tannen 1982:1). Van hierdic vraagstellings kan met mekaar oorvleuel en dit is derhalwe nie altyd moontlik om 'n presiese onderskeid tussen die verskillende vraagstellings aan te toon nie. 
Die werk van Harris (1991) wat alreeds in die voorafgaande afdeling beskryf is, is 'n voorbeeld van sosiale beskrywing van die kultuur van oraliteit. Botha (1990b) sluit by hierdie studie aan. Botha (1990b:41) voer aan dat dit die drukpers was, en nie geletterdheid op sigself nie, wat vir die verandering in kulture verantwoordelik was, aangesien die hoeveelheid geletterdes as gevolg van hierdie verandering toegeneem het. Wat die ontstaan van die Bybel betref, kan ons nie van 'n suiwer mondelinge kultuur praat nie, maar eerder van 'n 'scribal culture'. Hiermee word daar verwys na 'n kultuur wat met die verskynsel van skrif bekend was, maar in wese mondeling gebly het. Diktering, resitasie, memorisering en die spesifieke opleiding van sekere persone in die gebruik van skrif, was eie aan sulke kulture: 'n Geskrewe teks was in die woorde van Ocham (in Botha 1990b:42) 'something conceived as realizable only in the act of reading aloud'. Outeurs het hulle 'tekste' geskryf deur te dikteer. In sulke kulture is daar grootliks gekommunikeer deur te praat en te hoor en in 'n mindere mate deur te lees en te skryf.

Psigologiese vraagstellings gaan gepaard met die sosiologiese ondersoek. In beide die werk van Harris (1991) en Botha (1990b) word die vraag gestel na die invloed van die kultuur van oraliteit op die denkwyse van mense wat hulle in dié kultuur bevind. In sy artikel, getiteld Mute manuscripts: A neglected aspect of ancient communication, dui Botha (1990b:37) aan dat kommunikasiemedia of anders gestel, die wyse waarop mense met mekaar kommunikeer, hulle denkwyse beïnvloed. Volgens hom het 'n nuwe kommunikasiemedium denke oor ruimte en tyd verander. So het geletterdheid 'n nuwe omgewing geskep waarin kritiese en skeptiese denke floreer, aangesien 'n kontinue kritiese tradisie slegs moontlik is indien skeptiese denke neergeskryf word om sodoende oor tyd en ruimte te kommunikeer (Goody, in Botha 1990b:38). Harris (1991:41) sou hier egter van Botha verskil, omdat kritiese denke volgens Harris ook in 'n mondelinge situasie moontlik is. Harris wys die spekulasie oor die invloed wat geletterdheid op die denkwyse van ongeletterdes het, af deur die volgende stelling te maak: '... little is known about the cognitive effects of literacy .... [T] he effects of literacy on individuals are not easy to judge ...' (Harris 1991:41). Volgens Botha is interpretasie afhanklik van die bestaan van skrif (Ong, in Botha 1990b:38). Die kommunikasiemedium beïnvloed dus die betekenis van dit wat gekommunikeer word en daarom is dit volgens Botha belangrik dat wanneer gepoog word om 'n teks binne sy historiese konteks te verstaan en te interpreteer, dit noodsaaklik is om die kommunikasiemedium (mondeling of skriftelik) waarin dit ontstaan het, te verstaan (Botha 1990b:39). Die afleiding wat op grond hiervan gemaak kan word, is dat die betekenis van sê nou maar 'n sekere uitdrukking in 'n mondelinge kultuur, verander wanneer dit in 'n literêre dokument $n t_{2}$-slag vind. Volgens sy beskouïng het suiwer oraliteit te make met kommunikasie wat nie :an moderne media (byvoorbeeld die boekdrukkuns) afhanklik is nie (Botha 1990b:40). 
Weli Mazamiza (1992) redeneer oor die oraliteitskwessie vanuit 'n bestudering van hedendaagse ongeletterde mondelinge kulture. In navolging van Marcel Jousse dui Mazamiza (1992:15) die volgende as kenmerke van 'n kultuur van oraliteit aan:

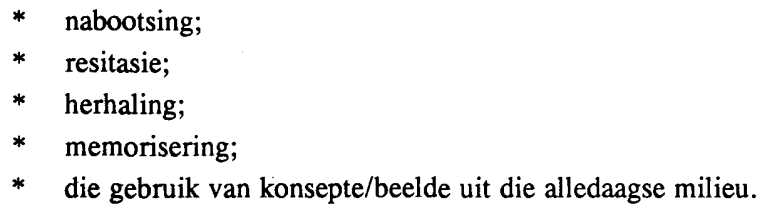

Hierdie kenmerke van 'n mondelinge kultuur word ook deur Botha (1990b:42-43) geïdentifiseer.

Botha omskryf die kultuur van oraliteit deur te fokus op die feit dat denke in mondelinge kulture nie dieselfde is as dié in 'n literêre kultuur nie. Aangesien daar in 'n mondelinge kultuur geen begrip van die historiese is nie, word die verlede as deel van die hede behou wanneer mense met mekaar kommunikeer. So bly die verlede dan in die hede ' $n$ teenswoordige werklikheid (Ong, in Botha 1990b:40). Dieselfde gedagte word ook by Loubser (1993) aangetref. Verwysende na 'n a-historiese tydsbegrip wil Loubser (1993:76) aandui dat die narratiewe gebeure wat vertel word, onmiddellik deel is van die hede. So word byvoorbeeld die heilsgebeure, wanneer dit verkondig word, beleef as teenswoordige gebeure wat die hede en die toekoms beheer.

Mazamiza (1992:5) spreek hom uit teen wat hy as ongeldige aannames met betrekking tot ongeletterdes beskou. So verwerp hy byvoorbeeld die gedagte dat ongeletterdes nie in staat is tot interpretasie of tot ' $n$ historiese bewussyn nie (met ander woorde, contra Loubser en Botha respektiewelik). Mazamiza herinner ons daaraan dat die intelligensie van ongeletterdes nie onderskat moet word nie.

Wat in sy betoog belangrik is, is sy pleidooi dat die orale kenmerke in die Bybel behou moet word in die oordrag van die Bybel aan mense in mondelinge kulture. Diesulkes identifiseer hulleself met die orale kenmerke in die Bybel, te wete met aspekte soos die verbeelding, konkreetheid en die direktheid van Bybelse uitdrukkings. Daar moet dus voorkom word dat die mondelinge vorm deur geletterdheid ingesluk word en sodoende van die moontlikheid as kommunikasiemedium ontneem word (Mazamiza 1992:13). 'Orality is more than the spoken word' (Mazamiza 1992:15). Die gesproke woord is ' $n$ woordgebeure wat lewenswyse kan beïnvloed. Die gesproke woord verbaliseer die lewenswyse van die vergange gemeenskap en verseker so kontinuiteit met die verlede. Hy beklemtoon in hierdie verband die belang van ' $n$ goeie geheue. Die gebruik van 'ou kennis' in die oordragsituasie is dus nie 'n vreemde verskynsel by mondelinge kulture nie. 
In P J J Botha se proefskrif, Die dissipels in die Markusevangelie, toon hy aan dat daar in ' $n$ mondelinge kultuur veral staatgemaak is op 'praat' en 'hoor'. Dit het beteken dat ' $n$ geskrewe teks eers tot verwesenliking gekom het, wanrieer dit hardop gelees en gehoor is (Botha 1989:2). Dit beteken egter nie dat die verskynsel van stillees nie onder geletterdes voorgekom het nie (kyk Gilliard 1993:693; contra Achtemeier 1990:15-17). Net soos die standpunt van Harris, is dit volgens Butha ongeldig om van 'n unieke orale styl te praat, aangesien die sogenaamde mondelinge kenmerke ook in 'n geskrewe situasie van leser en teks kan voorkom (Botha 1989:26). Sekere van die kenmerke kom egter meer in 'n praat-hoor situasie voor as in 'n teks-leser situasie (Botha 1989:27).

In die kultuur van oraiteit is daar met behulp van sekere tegnieke gekommunikeer. Dit is hierdie linguïstiese tegnieke wat vervolgens aandag sal geniet. Botha (1989:3140) bespreek die 'oral formulaic theory' van Parry en Lord, maar onderskei dan tussen retoriese strategieë aan die een kant en die orale kenmerke wat deur Parry en Lord uitgelig word. Die retoriese strategieë (Botha 1989:27-30) kom op die volgende neer:

* Herhalings wat in nabygeleë (daaropvolgende) reëls voorkom. Dit word as stoltegniek gebruik om sprekers tyd te gee om te dink oor dit wat hulle vervolgens wil sê.

* Parentese verwys na die kruisverwysings, voetnotas en verklarende opmerkings wat in die 'teks' - wat gepraat word - self aanwesig moet wees, aangesien daar nie in 'n mondelinge kommunikasiesituasie van voetnotas en hakies gebruik gemaak kan word nie.

* Parataksis dui op neweskikkende sinne in 'n additatiewe styl om opeenvolgende inligting weer te gee. Met bchulp van byvoorbeeld $\kappa \propto i$ kan inligting in 'n kompilasiestyl corgedra word. Koördinerende sinne kan op hierdie wyse eenvoudig gelys word.

* Retoriese vrae.

* Die oorgaan na die teenwoordige tyd.

* Sinne met 'n onvolledige konstruksie of onderbroke sinne.

* Onduidelike gebruik van voornaamwoorde.

* Inkonsekwenthede, aangesien 'n mondelinge komposisie spontaan en dikwels 'onvoorbereid' is. Die gevolg hiervan is dikwels 'n onlogiese struktuur. Meer 
aandag sal in toekomstige navorsing aan die onderskeid tussen voorbereide en onvoorbereide kommunikasie in 'n mondelinge situasie gegee moet word: dit is byvoorbeeld 'n vraag of onvoorbereide kommunikasie altyd met 'n onlogiese struktuur gepaard gaan. Soos later in die bespreking aangedui sal word, is 'n logiese struktuur egter nie 'n totale onmoontlikheid in 'n mondelinge kommunikasiesituasie nie.

Hierdie kenmerke is egter nie uniek aan 'n mondelinge oordragsituasie nie (Botha 1989:31) en daarom is dit nodig om die kenmerke onder oë te neem wat eie is aan 'n kultuur van oraliteit.

Volgens Parry en Lord se 'oral formulaic theory' het 'n sanger/verteller in ' $n$ mondelinge sitiasie vanuit 'n geïnternaliseerde 'grammar of poetry' formules gegenereer (Lord 1960:35-36; vgl Botha 1989:32). Die sanger/verteller het as 'n talentvolle individu hierdie mondelinge tradisionele materiaal by wyse van lewende, dinamiese en unieke komposisies oorgelewer. In die mondelinge oordrag is van formules en temas gebruik gemaak wat vanuit bestaande en bekende tradisies en vanuit die verhaal self ontleen is (Botha 1989:32). Hieruit kan derhalwe afgelei word dat tradisionele materiaal nie letterlik, woord vir woord, oorgelewer is nie, maar dat dit telkens opnuut in 'n nuwe komposisie omskep is (contra Funk 1992).

Lord (vgl Botha 1989:33-37) onderskei dan die volgende as kenmerke van die mondelinge tradisionele komposisie:

* Komposisie in uitvoering:

'n Voordrag is nie vooraf beplan nie. Die komposisie van 'n gedig geskied ten tyde van die uitvoering self. Die digter is dus meer as net 'n kenner en draer van die tradisie, maar hy/sy is in der waarheid 'a creative artist making tradition' (Lord 1961:13; vgl Botha 1989:308). Dit het daartoe gelei dat daar variante weergawes van dieselfde tradisionele materiaal tot stand gekom het, terwyl daar nie sprake is van 'n oorspronklike weergawe nie. Hierdie kenmerk kan egter nie ongekwalifiseerd op enige komposisie in die mondelinge situasie van toepassing gemaak word nie. 'n Historikus soos Josefus sou moontlik anders te werk gegaan het in die komponering van sy werke. Onvoorbereide voordrag is egter nie die enigste moontlikheid in 'n mondelinge kommunikasiesituasie nie. Dit blyk dat hierdie punt afsonderlike aandag moet geniet en daarom sal dit later meer breedvoerig aan die orde kom. Op die oog af is die kenmerke van Parry en Lord baie hipoteties 
van aard en te teoreties. Die gevaar hiervan is dat dieselfde dooie punt wat die Formgeschichte gekortwiek het, ook hier' $n$ wesenlike gevaar mag wees. Om hierdie rede is ' $n$ multi-dissiplinêre benadering so belangrik in die ondersoek na die kultuur van oraliteit.

* Rol van die gehoor:

Die gehoor was mede-bepalend vir die betekenis van dit wat voorgedra is, aangesien die verteller/sanger in elke situasie met sy/haar gehoor rekening moes hou. Dit het van die sanger 'n 'dramatic ability', 'n 'narrative skill', konsentrasie, spoed, buigsaamheid en kennis van die tegnieke van orale komposisie vereis, sodat die aandag van die gehoor behou kon word (Lord 1960:16).

Loubser (1993), wat 'n studie op die Shembe-beweging gedoen het, dui in aansluiting by Lord kontekstualiteit as een van die eienskappe van ' $n$ mondelinge kultuur aan. Kontekstualiteit speel 'n belangrike rol in die oordrag van informasie, aangesien die betekenis van ' $n$ woord afhanklik is van die lewendige konteks waarbinne dit gebruik is (Ong, in Loubser 1993:74). Die gesproke woord is nie staties of abstrak nie, maar kan eerder as 'n woordgebeure getipeer word. Die gesproke woord dra derhalwe 'n inherente krag wat beroering en verandering te weeg kan bring. By implikasie sou hier die afleiding gemaak kan word dat 'ou kennis' nuut geïnterpreteer kan word in 'n nuwe konteks.

\section{* Formules en temas:}

Formules en temas as orale tegnieke - dit wil sê tegnieke wat eie aan 'n mondelinge kommunikasiesituasie is - het deel van die sanger/verteller se repertoire geword en dit hou op hulle beurt verband met die sanger/verteller se ervaring met verhale en met sy/haar 'opleiding' (Botha 1989:34). Die konsepte 'formule' en 'tema' kan soos volg omskryf word:

'n Formule is 'n stereotipe frase wat uit vaste woordelikse en metriese kombinasies bestaan het en dan as sulks in sinne gebruik is (Lord 1960:30; vgl Botha 1989:34). 'n Digter kan van bestaande formules gebruik maak of 'nuwe' formules skep na analogie van bestaandes (Lord 1960:36-37, 42-46; vgl Botha 1989:34). Formules - soos Lord (1960:42-45) dit verstaan - kan ook gedefinieer word as herhalings op die leksikaliese/sintaktiese vlak in die oppervlaktestruktuur. Ontwikkelings na Lord het aangetoon dat formules nie losstaan van die semantiese dieptestruktuur 
nie. Basies is die 'formule' die 'stringing together of standard elements' (Cully, in Botha 1989:42). Deur middel van die gebruikmaking van formules word kennis opgeroep wat alreeds aan 'n gehoor bekend is. Die belangrike is dus dat in die mondelinge tradisie formulêre uitdrukkings nie opsigself betekenis het nie, maar dat dit na die alreeds bekende verwys (Tannen 1982:1-2; vgl in Botha 1989:42). Olson (in Tannen 1982:2) lê veral daarop klem dat betekenis deur die konteks bepaal word. Hierdie siening verteenwoordig 'n uitbreiding op die definisie wat deur Lord gegee word.

'n Tema word deur Lord (1960:4; vgl Botha 1989:34) omskryf as 'repeated incidents and descriptive passages'. Lord (1960:68) noem die 'groups of ideas regularly used in telling a tale in the formulaic style of traditional song' die " themes" of the poetry'. Dié gedagtes word herhaaldelik aangetref in die werke van 'n spesifieke outeur en op 'n wyer basis in die werke van outeurs wat hulle in dieselfde gemeenskap bevind. Iemand wat in so 'n gemeenskap opgroei, sou dieselfde stories voortdurend gehoor het. Op hierdie wyse sou hy/sy vertroud geraak het met formules en temas wat voortdurend in die oorvertel van die stories gebruik is. Die implikasie hiervan is dat die formules en temas nie onafhanklik van mekaar bestaan het nie. Die afleiding kan gemaak word dat sekere formules kenmerkend van sekere temas was (Lord 1960:69). Lord (1960:94; vgl Botha 1989:35) dui verder aan dat: 'In a traditional poem ... there is a pull in two directions: one is toward the song being sung and the other is toward the previous uses of the same theme'. In 'n sekere sin kan dit met die Formgeschichte se konsep 'vorme' vergelyk word, alhoewel 'n 'tema' meer op die inhoudelike vlak as die 'formule' funksioneer. Dit blyk egter dat Botha die formgeschichtliche se vorme van temas onderskei, in die sin dat die Formgeschichte se vorme voor die opskrifstelling daarvan 'n onafhanklike bestaan gevoer het. Temas maak die onderdele van 'n komposisie uit en het derhalwe nie 'n onafhanklike bestaan voor die opskrifstelling daarvan nie. Temas is nie onafhanklike literatuurtipes wat binne sekere sosiale omstandighede sekere funksies gehad het nie, maar is bloot funksioneel in die sin dat dit die verteller in staat stel om verhale te leer of te ontwikkel (Botha 1989:48). Lord (1960:98) dui ook aan dat sekere temas met mekaar geassosieer is en in die meeste gevalle saam met mekaar gebruik is - die een tema het die ander op 'n logiese wyse opgeroep. Volgens Botha (1989:48) onderskei Lord wat 'n tematiese komposisie betref, tussen: 
* 'composition theme' waarin 'n hoë frekwensie van woordelikse ooreenkomste voorkom, en

* 'type scene' waarin 'n vasgestelde stel van elemente voorkom.

Volgens Funk (1992:2) word diskoersmateriaal oor die algemeen verbatim oorgelewer (contra Lord), terwyl in die geval van narratiewe materiaal dit alleen die kernsake is wat oorgelewer word. Hy stel dit soos volg: 'The outline of the story was transmitted as "gist". Gist means that the general sense was transmitted, not the precise words: the storyteller was free to restate in his/her own words what was remembered' (Funk 1992:4). Die verteller het dus dit wat hy/sy onthou in sy/haar eie woorde oorgelewer. Hierby het die verteller ook van sy/haar eie 'transitional elements' gebruik gemaak om die oorgelewerde materiaal aan te pas of om nuwe materiaal te skep. Dit is moontlik redaksionele kommentaar wat die outeur gebruik om verskillende tonele met mekaar in verband te bring, byvoorbeeld soos die in Matt 8:1 en Luk 5:12 (Funk 1992:2). Funk (1992:3) is in hierdie verband van mening dat die inleiding en slot van narratiewe materiaal nie stabiele elemente is nie. Die storieverteller kan dit na vrye keuse verander, weglaat of uitbrei.

In die proses van die oorlewering en die versmelting van Jesus-tradisies is sekere clichés woord vir woord oorgelewer en dan in tematies verwante tekste ingevoeg. In hierdie verband moet ' $n$ mens jou kan voorstel dat bepaalde 'achievement lists' die rondte gedoen het. Hierdie lyste het uit 'n versameling van profetiese tekste bestaan. Die oorsprong van hierdie lyste was mondeling en dit is ook mondeling oorgelewer. Op hierdie wyse het die lyste dan as hulp by die geheue van die vertellers gefunksioneer. Soms is materiaal by die lyste bygevoeg wat nie 'n skriftuurlike oorsprong gehad het nie, maar as dit eens bygevoeg is, is daar van die standpunt uitgegaan dat dit hulle oorsprong in die Skrif gehad het. Baie min mondelinge oorleweraars het eers die Griekse Bybel gaan raadpleeg om die lyste te verifieer of om die akkuraatheid daarvan te kontroleer. Aangesien die vertellers die tekste vanuit hulle geheue aangehaal het, kan dit met redelike sekerheid beweer word dat hulle oor 'n repertoire van sulke aanhalings beskik het.

Funk sluit dus nou aan by die teorie van Lord waarna ons reeds verwys het. Lord het ook melding gemaak van 'n sogenaamde skoling wat tot 'n repertoire aanleiding gegee het. Verder verwys Funk ook na 'n aantal clichés wat moontlik deur Lord se teorie as formules aangetoon kan word. Ook die begrip 'gist' kan in verband gebring word met wat Lord as temas aangedui het.

By Botha (1989:50; vgl Lord 1960:94) word die gedagte aangetref dat '... historiese kennis "voortleef" deur middel van 'n baie bekende tema .... [D]it is egter meer as net aansluiting by 'n algemene motief ... die woordelikse herhalings ... asook die 
struktuur ... wys na tematiese komposisie'. Hieruit kan derhalwe afgelei word dat 'nuwe' kennis deur middel van 'ou' kennis oorgedra is. Botha (1989:51) stel dit meer pertinent wanneer hy meld dat 'a given essential idea', dit wil sê 'n tema, deur die tradisie ('ou' kennis?) gereguleer word. Die tradisie het die verteller behoudend te werk laat gaan met sy stof, maar terselfdertyd ook ruimte gelaat vir 'vernuwende' gedagtes. Die gedagte van kontinuïteit met die verlede word verder deur Botha (1990b:40) beklemtoon deurdat hy daarop wys dat herhaling 'n groot rol in mondelinge kulture speel. So is daar byvoorbeeld gereeld oor die wet gepraat, sodat verhinder kan word dat dit nie vergeet word nie. Walter Ong (in Botha 1990:40) formuleer dit soos volg: '... storage and communication are virtually the same thing ....' Eie aan die kultuur van oraliteit is die kollektiewe geheue waardeur informasie in stand gehou word deur middel van memorisering en nabootsing. Die beginsel van kontinuiteit met die verlede sal in die volgende afdeling verdere aandag geniet.

\section{* Konserwatisme:}

In mondelinge kulture sien die digter homself/haarself as die 'defender of the historic truth of what is being sung' (Lord 1960:28; vgl Botha 1989:35) en is ook oortuig daarvan dat hy/sy die tradisie 'presies' sing soos hy/sy dit gehoor het. Verskille tussen die digter se weergawes en dit wat hy/sy gehoor het, kan egter wel aangetoon word. Die konserwatisme in die mondelinge tradisie-oorlewering is geleë in die bewaring en handhawing van die kernidee/sentrale temas van die tradisie. Hierdie verskynsel hou verband met die gebruikmaking van formulêre uitdrukkings waardeur bestaande kennis oorgedra word, hoewel daar met konserwatisme, wat temas betref, nie die bewaring van woordelikse ooreenkomste bedoel word nie. In die teorie van Lord word egter nie ruimte gelaat vir die nuwe kennis wat die digter deur middel van die bestaande kennis of formules wil oordra nie (contra Patte 1987:10).

Wat die onderhawige ondersoek betref, word die klem op die sogenaamde formulêre styl gelê. Volgens geleerdes soos Lord, Wittig en Gray (kyk Botha 1989:37) is formulêre styl die belangrikste linguïstiese kenmerk van gesproke kommunikasie.

Die vraag na die voorkoms van voorbereide en onvoorbereide voordrag en die vraag na die gestruktureerdheid daarvan sal in die volgende bespreking opgeklaar word.

Lohr (1961:404) beoog om in sy werk daardie orale tegnieke te bespreek wat 'n komposisie tot 'n eenheid saamsnoer. Volgens hom is dit die volgende: proloog, epiloog, herhalende reëls, antisipasie, retrospeksie, temas en strukture. Hierdie teg- 
nieke verleen struktuur aan dit wat gekommunikeer word (kyk Lohr 1961:404). Hy lê klem op die feit dat skrifgeleerdes en digters die bewaarders van mondelinge tradisie is. Hulle is deur voorgangers in hulle ambag om stories op 'n bepaalde wyse oor te vertel; geskool. Daar is van hulle verwag om met die konserwatiewe vooroordele van hulle gehore rekening te hou, aangesien die sukses van hulle voordrag deur die reaksie van die gehoor bepaal is. Dit was daarom deel van hulle 'skill' om aan die nuwe elemente in die oordrag ' $n$ tradisionele kleur te gee. Soos by Lord (kyk Botha 1989:34) word die gebruik van eeue-oue formules - naas die gebruik van temas - as die belangrikste tegniek vir mondelinge komposisie gesien. Hierdie formules is ingespan om ou en nuwe materiale tot ' $n$ kunsvolle eenheid saam te snoer. Deur die gebruikmaking van antieke tegnieke (formules) en die integrering daarvan met nuwe stof in stereotipe vorms word effektiewe mondelinge kommunikasie bewerk.

In hierdie paragraaf sal die reeds genoemde tegnieke waarmee 'n eenheid binne 'n mondelinge komposisie bewerkstellig is, meer volledig bespreek word (Lohr 1961:408434). Hierdie tegnieke was eie aan 'n mondelinge oordragsituasie waar daar deur middel van ' $n$ formulêre styl gekommunikeer is. Deur middel van hierdie tegnieke is struktuur aan 'n voordrag gegee (vgl Lohr 1961:404).

\section{Herhaling van formules:}

* Inclusio - 'n woord of frase word aan die begin of einde van 'n gedeelte herhaal; dit loop uit op soortgelyke inleidings- en afsluitingsformules.

* Refrein - integreer groter eenhede tot ' $n$ eenheid.

* Antisipering - berei die hoorder voor op dit wat nog gaan gebeur deur middel van 'n proloog wat die tema bekend stel of deur middel van profesieë, drome ensovoorts.

* Retrospeksie - bind dit wat later in die verhaal gaan gebeur, aan dit wat vooraf plaasgevind het.

* Tematiese ontwikkeling vind ook plaas op grond van die herhaling van formules. 'n Formule kry betekenis in die konteks waarin dit gebruik is en roep terselfdertyd die betekenisse/beelde op van ander kontekste waarin dit in die verlede gebruik is. Dit hou met ander woorde die geskiedenis lewendig. Deur die herhaling van die formule word die tema beklemtoon en verder uitgebou. Hierdie is ' $n$ belangrike insig van Lohr wat ook deur Tannen (1982:1-2) en Botha (1989:50; 1990:40) gesuggereer is. 
Die beginsels ter sprake by strukturering

* Aangesien die verteller slegs op een ding op 'n keer kan konsentreer, is dit nodig dat daar ' $n$ eenheid tussen die afsonderlike gedeeltes van 'n komposisie bewerkstellig moet word. Hier word verwys na die bewustelike samevoeging van afsonderlike tradisiestukke. Die verteller het op die manier struktuur aan sy voordrag gegee. In skriftelike tekste kan die mondelinge reste weer opgespoor word.

** Stof met soortgelyke onderwerpe/temas word saam gegroepeer om een gedagte oor te dra. Sodoende kan daar op een primêre gedagte in elke mikro-eenheid gefokus word. Luz (1991:38) wys daarop dat die outeur van die Matteusevangelie byvoorbeeld, by uitstek kommunikeer deur gebruik te maak van tematies verwante blokke. Die outeur 'brackets a block solidly' (Luz 1991:38) om sodoende die blok 'n duidelike funksie te gee in die verhaallyn. So byvoorbeeld het die samevoeging van gelykenisse in Matteus 21:28-22:14 'n duidelike funksie in die voorbereiding op 'n tema met betrekking tot die groot afrekening van Israel.

** Sleutelwoorde word herhaal om by te dra tot die ontwikkeling van 'n sekere idee. Ook deur die gebruik van hierdie tegniek word die afsonderlike dele van die komposisie tot 'n eenheid gebind.

* Die samesteller kan van verskeie strukturele tegnieke gebruik maak om afsonderlike passasies saam te bind. As voorbeeld kan onder andere die konsentries simmetriese struktuur (abc-cba) genoem word. Wanneer 'n sanger 'n nuwe lied geleer het, het hy/sy dit nie woord vir woord geleer nie, maar slegs die plan/struktuur van die lied. Die struktuur het die gehoor ook gehelp om die werk te onthou.

Die onderskeid wat tussen Lohr en Lord aangetoon kan word, is die aangeleentheid met betrekking tot 'prepared' en 'unprepared speech'. Lord (1961) beskryf eerder 'n situasie van onvoorbereide oordrag, terwyl Lohr 'n situasie van voorbereide voordrag in die oog het. In albei situasies word daar wel met orale tegnieke rekening gehou, aangesien beide tipes kommunikasie voor 'n gehoor gelewer is. Lohr (1961:404) en Lord (in Mazamiza 1992:18) is albei oortuig daarvan dat komposisies in die mondelinge kommunikasiesituasie struktuur gehad het. Botha (1989:30-31) is egter onduidelik oor die gestruktureerdheid van mondelinge komposisies. Soos reeds aangedui, sluit Mazamiza by Lord aan met betrekking tot die oortuiging dat die idee dat orale literatuur vormloos en ongestruktureer is, 'n populêre wanopvatting is. Achtemeier 
(1990) spreek ook die probleem van struktuur in mondelinge voordrag aan. Volgens Achtemeier (1990:20) het die vertellers 'verbal clues' gebruik om luisteraars te lei in hulle verstaan van die '.. organization of the kind of complex writings that are found in the New Testament ....' Achtemeier is soos Mazamiza van mening dat orale komposisies nie sonder struktuur was nie. Hy sluit by Lohr aan in sy verduideliking van die tegnieke wat gebruik is om mondelinge komposisies te struktureer. Hierdie tegnieke is ook deur die verteller gebruik om sy stof te memoriseer (Achtemeier 1990:7). Hierdie tegnieke is derhalwe in situasies van voorbereide en onvoorbereide voordrag toegepas. Achtemeier lê veral klem daarop dat die oordragsituasie een van 'praat' en 'hoor' was (contra Gilliard 1993:693). Die lees en selfs die skryf van manuskripte het altyd gepaard gegaan met klank, dit wil sê dat die woorde wat gelees of geskryf is, in die meerderheid van gevalle hardop uitgespreek is. Die vorm waarin antieke tekste geskryf is, het ook die lees van geskrifte bemoeilik. Aangesien alle materiaal bedoel was om gehoor te word, is dit vanselfsprekend dat die luisteraars sensitief sou wees vir 'oral/aural effects' (Achtemeier 1990:18). Daarom dui hy aan dat 'the alternative to visual structuring of a manuscript to indicate organization of meaning is to include oral indications of structure within the material' (Achtemeier 1990:17). Die tegniek wat volgens my interpretasie deur Achtemeier as die belangrikste aangedui word, is die tegniek van herhaling. Die tegniek van herhaling word toegepas deur onder andere van herhalende inleidingsformules en die tegniek inclusio gebruik te maak (Achtemeier 1990:18). Achtemeier lewer 'n belangrike bydrae deur klem te lê op die herhaling van formules. Komplekse strukture is derhalwe eie aan orale komposisies (kyk Lord, in Mazamiza 1992:18).

Met die literêre neerslag van 'n mondelinge teks word die vrye mondelinge teks 'n gefikseerde teks en word dit van die sosiale konteks losgemaak (Mazamiza 1992:2124). Literariteit vra dus hervertolking in die konkrete lewensituasie. In die bestudering van gefikseerde tekste wat mondelinge reste vertoon, is 'n ondersoek na die sosiale en politieke konteks waarin die geskrif ontstaan en oorgelewer is, baie belangrik. Dit dra daartoe by om die inhoud van die geskrif teen die regte agtergrond te interpreteer. Dit is presies die saak wat deur Theissen aangeraak word. Hiermee word nie alleen verwys na die herhalende situasies waarna die Formgeschichte met die term Sitz-im-Leben verwys nie, want Theissen wil spesifiek die historiese situasie ondersoek waarbinne die teks beslag gekry het. Soos die voorafgaande ondersoek aangedui het, is in 'n mondelinge oordragsituasie veral van reeds bekende formules gebruik gemaak (Lohr 1961:405; vgl Lord 1960:42-43). Tannen (1982:2) het aangedui dat die formules gebruik is om reeds bestaande kennis by die hoorder op te roep. Die formules is egter 
nie verbatim oorgelewer nie, maar is soms angepas (Lord 1961:34). Lohr (1961:406) stel dit as volg: 'An adherence to tradition ... led first to the maintenance of many very old formulae, and then to the casting of new materials in the same stereotyped mold'.

Uit bostaande bespreking het dit duidelik geblyk dat kontinuïteit met die verlede kenmerkend van ' $n$ kultuur van oraliteit is. Die vraag is nou watter kennis deur bekende formules in die betrokke historiese situasie opgeroep is en wat die verteller/ outeur met behulp van hierdie formules aan sy/haar lesers/hoorders wou oordra. In die volgende afdeling sal aandag gegee word aan hierdie vraagstelling. In die bespreking sal die Matteusevangelie as voorbeeld dien, aangesien formulêre styl 'n kenmerk van hierdie evangelie is (Luz 1991:36; vgl Lohr 1961:407). Daar sal spesifiek aandag gegee word aan die artikel van Lohr, aangesien hierdie artikel formulêre styl as dié kenmerk van die kultuur van oraliteit uitwys. Die beginsel dat formules 'ou kennis' kontinuiteit met die verlede - oproep, sal vervolgens op die Matteusevangelie toegepas word om te bepaal of dié evangelie geskik is vir verdere studie in die lig van die kultuur van oraliteit.

\section{FORMULERE STYL IN DIE MATTEUSEVANGELIE}

Lohr (1961:416) sê oor formules die volgende: 'They [formulae] are qualified by the whole context in which they figure, and they bring to that context the images derived from other contexts in which they figured in the past'. Hiervolgens neem formules ' $n$ groter beklemtoonde betekenis aan elke keer wanneer dit herhaal word en dra so by tot die tematiese ontwikkeling wanneer selfs die mees uiteenlopende materiaal saamgevoeg word. 'The interplay between formula and context is able to keep alive (a) history' (Lohr 1961:416). Hiermee beklemtoon Lohr die beginsel van kontinuïteit met die verlede. Lohr lig hierdie tese toe met ' $n$ bespreking van die formule 'Seun van die Mens', soos dit in die Matteusevangelie voorkom.

Die formule 'Seun van die Mens' word herhaalde kere in die Evangelie van Matteus aangetref. Volgens Lohr (196i:418) onderbou die formule die ontwikkeling van die tema aangaande Jesus se dood en opstanding met die gepaardgaande belofte van Jesus se 'ewigheid'. Dit is ' $n$ belofte dat die 'Seun van die Mens' vir ewig by die gelowige teenwoordig sal wees. Dit is ook die hooftema van al die evangelies. Die lydingsverhaal kom egter eers aan die einde van die evangelies voor, insluitende die Matteusevangelie. Tog word dié tema deur die hele evangelie lewend gehou deurdat die evangelie die geloof van die leser voor oë het. Die verskillende motiewe in die tradisiemateriaal word volgens Lohr tot 'n eenheid saamgebind deur onder andere die gebruik van die formule 'Seun van die Mens'. Deur middel van hierdie formule word 'n basiese paradoks tussen Jesus se dienskneg-gestalte en sy mag in hemel en op aarde 
lewendig gehou. Die formule word herhalend gebruik in Matteus 9:6; 8:20;12:8; $11: 19 ; 10: 23 ; 11: 3 ; 13: 41$ en $20: 28$. In Matt 12:39-41 word die figuur van Jona met die 'Seun van die Mens' in verband gebring. Die verhaal van Jona roep (bekende?) beelde van hergeboorte en 'ewigheid' op. Dit word hier in verband gebring met die 'Seun van die Mens'. Die opstanding van Jesus uit die dood word met die Jona-tema geantisipeer. Die hoogtepunt van die gebruik van die Seun van die Mens-motief in die eerste helfte van die Matteusevangelie, is die motief van 'ewigheid' wat later vertel word. Latere verwysinge na die lyding van Jesus moet daarom in die lig hiervan gelees word. In die tweede helfte van die evangelie word direkte verwysings na die lyding van Jesus aangetref. Die Seun van die Mens-motief herstel die balans wanneer daar na die lyding van Jesus verwys word en verseker so dat dié aankondigings in die regte lig beskou word.

In die volgende gedeeltes word die Seun van die Mens-motief weer eens aangetref en enersyds in verband gebring met die dood, lyding en vernedering van Jesus en andersyds met sy verheerliking (kyk Matt 16:27;17:9, 12, 22;19:28; 20:18, 28; $24: 27-44 ; 25: 31 ; 26: 2,24,45,64)$.

Matteus gebruik dus bekende temas en herhaalde formules om by die gehoor die regte gesindheid tot stand te bring, sodat hulle die 'katastrofe' aan die einde van die evangelie in die regte lig sal beskou. Die temas en die formules is dan in sekere kontekste gebruik, wat die dieper betekenis aan die formules en temas gegee het. Dit is duidelik dat die gebruik van 'n formule die kontekste oproep waarin die formule van tevore gebruik is. Hierdie werkwyse bewerkstellig die eenheid van die evangelie (Lohr 1961:418-419).

Die verband tussen die formule 'Seun van die Mens' en kontekste waarin dit in die verlede (die tyd voor die skryf van die Matteusevangelie) gebruik is, word egter nie genoegsaam deur dié voorbeeld van Lohr (1961:416-419) geïllustreer nie. Die gebruik van die formule 'Seun van die Mens' en die funksionaliteit daarvan in die verskillende kontekste in die Matteusevangelie dui duidelik aan dat die kennis van elke konteks waarin die formule gebruik is, nuttig is vir die verstaan van die volgende konteks en uiteindelik van die hele ontwikkeling van die evangelie.

Loubser (1993:74) het ingesien dat Patte se werk op Paulus betekenis het vir oraliteitsnavorsing, alhoewel Patte self nie die kultuur van oraliteit bestudeer nie. Net so is die werk van Patte ook relevant vir die studie van die Evangelie van Matteus in die lig van die kultuur van oraliteit. Verskeie redes kan hiervoor angevoer word. Patte (1987:9) voer aan dat sekere konnotasies aan begrippe geheg word. Hierdie konnotasies word aan die begrippe geheg op grond van die kontekste waarin dit in die verlede gebruik is. Die nuwe konteks waarin 'n begrip gebruik word, lei weer tot nuwe 
konnotasies wat ook aan die begrip toegeken kan word. Hierdie afleiding staan in verband met die insig dat '... oral texts are "speech acts" in the true sense of the word' (Patte, in Loubser 1993:74). Die kontekste waarin 'n begrip in die verlede gebruik is en die nuwe konteks waarin 'n begrip gebruik word, dra dus by tot die betekenis wat aan die begrip geheg word. Dit lyk derhalwe of die werk van Patte verband hou met die insig van die navorsing na die formulêre styl in oraliteitskulture dat bekende inligting deur middel van formules met behulp van nuwe temas gekommunikeer word. So bied die werk van Patte 'n ideale aanknopingspunt om in die Matteusevangelie mondelinge reste te identifiseer.

Daniel Patte bou sy ondersoek op die Evangelie van Matteus rondom die oortuiging dat die outeur van die Matteusevangelie sy geloof aan sy hoorders wil kommunikeer. Onder 'geloof' verstaan hy dan 'n 'system of convictions'. Dit is juis hierdie geloofsoortuiging van die evangelis wat die verskillende diskoerse in die Matteusevangelie tot 'n eenheid bind (Patte 1987:4). Patte veronderstel dat 'n outeur wat so 'n belangrike boodskap wil oordra, seker maak dat hy/sy nie verkeerd verstaan sal word nie. Om dit te verseker word nie net dit gesê wat die outeur wil kommunikeer nie, maar veral ook dit wat hy/sy nié wil sê nie: '... (we) more or less spontaneously set an apposition between what we actually want to say and what we do not want to say ....' (Patte 1987:6). Om die hoofpunte of die oortuigings te identifiseer wat die teks wil oordra, is dit volgens Patte noodsaaklik dat die apposisies wat hierdie oortuigings bevat, eers geïdentifiseer moet word. Hy stel dit soos volg: '... explicit appositions can be viewed as a direct expression of the author's convictions' (Patte 1987:7).

Patte onderskei tussen semantiese en narratiewe apposisies. 'n Semantiese apposisie spesifiseer die konnotasie wat aan 'n situasie, persoon, frase of woord geheg word en derhalwe noodsaaklik is vir die verstaan van 'n begrip. Narratiewe apposisies is dit wat ' $n$ verhaal in beweging bring en daaraan struktuur gee. Dit vereis 'n opeenvolging van handelinge waarin een handeling die oorsaak van 'n ander handeling is. Hierdie opeenvolgende handelinge is gewoonlik konflikterend van aard: Handeling en teen-handeling, optrede en teen-optrede, 'action' and 'counteraction' (Patte 1987:7). Narratiewe en semantiese apposisies staan nie los van mekaar nie. Wanneer die semantiese apposisies ondersoek word, moet alle moontlike konnotasies wat aan die begrippe toegeskryf kan word, onder oë geneem word. Op hierdie punt is die resultate van die historiese navorsing baie belangrik, omdat dit 'n bydrae lewer tot die bepaling van die konnotasies wat begrippe in die kulturele milieu waarin die teks geskryf is, mag hê (Patte 1987:9). Die ondersoek van Theissen na die sosiale en politieke konteks waarin 'n geskrif tot stand gekom het, kan 'n bydrae lewer om die konnotasies wat aan begrippe (formules) geheg is, vas te stel. Hierdie inligting kan daartoe bydra dat die sosiale konteks van 'n gefikseerde teks beter bepaal kan word (vgl Mazamiza 1992:2124). 
Patte merk verder op dat 'n boodskap alleen suksesvol oorgedra kan word, as die gehoor aan wie dit gerig is, in ag geneem word. 'n Boodskap word oorgedra deur middel van woordeskat, beelde en simbole wat aan die gehoor bekend is. Daar word dus van die bestaandelou kennis van die gehoor gebruik gemaak om iets nuuts te sê. In die Matteusevangelie byvoorbeeld, verwys die 'ou kennis' van die gehoor na dit wat hulle alreeds glo en na aanleiding van dit wat hulle alreeds in die evangelie gelees of gehoor het (Patte 1987:10). Hier is dus sprake van 'n spanning tussen die bekende $\in$ die onbekende. Matteus kommunikeer deur bekende sake te stel en dan nuwe sake te propageer. 'This expression of the author's convictions in terms of the reader's old knowledge is what we shall call the themes of the passage' (Patte 1987:10). Die enbekende sake wat die outeur deur middel van die bekende kommunikeer, word temas genoem. Die oortuigings van die outeur is die temas. Dit waarvan die outeur die gehoor wil oortuig, is met ander woorde die temas van sy/haar boodskap. 'In terms of the reader's old knowledge, Matthew hopes to communicate to his readers something that he expects that they do not know - something new' (Patte 1987:10).

Dié insig van Patte gee aanleiding tot 'n verbreding van die definisie van temas wat vroeër in hierdie studie gegee is. Temas verwys derhalwe nie net na 'ou kennis' nie, maar verteenwoordig ook die 'nuwe kennis' wat die outeur wil oordra. Die nuwe konteks waarin 'n outeur die ou temas of formules gebruik, dra by tot die nuwe betekenis wat met behulp van die formules en temas verwoord word. Dit is ook belangrik om te onthou dat formules op sigself geen betekenis het nie (vgl Tannen 1982:2), maar as die draer van temas funksioneer. Wanneer Matteus, byvoorbeeld, Jesus die bergrede laat lewer, wil hy hê dat die lesers Hom met Moses moet identifiseer (ou kennis). Jesus is egter ook anders as Moses en dit is vir Matteus belangriker. Daarom is dit in hierdie ondersoek, volgens Patte, nodig om die posisie van die lesers in ag te neem. Dit is belangrik om te verstaan wat die lesers geweet het voordat hulle die evangelie begin lees/hoor het en telkens ook in ag te neem wat hulle weet terwyl hulle in die lees/hoor van die evangelie vorder (Patte 1987:11).

Die beginsel wat Patte hier ter sprake bring, kan myns insiens veral van toepassing gemaak word in die studie van die kultuur van oraliteit. Ons het reeds daarop gewys dat daar in hierdie kulture by uitstek van formules gebruik gemaak word. In hierdie tipe kultuur word ook baie klem gelê op die moontlikheid van die geheue om te memoriseer. Deur die gebruikmaking van formules kan bestaande kennis by die hoorder opgeroep word. Op hierdie manier kan die verteller/skrywer die onbekende/nuwe in terme van die bestaande oordra. Dit bly egter 'n vraag of die ongeletterde hoorder wel sodanige kennis van bepaalde formules sou hê en dit met sekere sake in verband sou bring. 
Indien dit wel algemeen was om kennis van formules te hê, dan sou die implikasie hiervan wees dat sekere formules aan sekere bekende temas gekoppel was (vgl Lord 1960:69). Volgens Patte (1987:10) word die onbekende/nuwe kennis as temas getipeer. Die vraag is: wat kan as die bekende/ou kennis van 'n bepaalde gehoor aangedui word? Sou dit alleen kennis wees wat die outeur alreeds aan die leser/hoorder oorgedra het - soos wat Lohr se voorbeeld met betrekking tot die Seun van die Mens impliseer of sou dit ook die voorafkennis van die leser/hoorder insluit, voordat hy/sy nog die evangelie begin lees het? Die kommentaar van Ulrich Luz op die Matteusevangelie werp myns insiens lig op hierdie vrae.

Die tendens om die onbekende/nuwe deur middel van die bekende oor te dra, kan in die lig van die tweebronne-teorie as oplossing van die sinoptiese probleem toegepas word op Matteus se gebruikmaking van die Markusevangelie en $Q$ as bronne van 'bekende' kennis. Baie van die woordeskat en derhalwe formules wat in die Matteusevangelie gebruik word, is volgens Luz nie nuwe skeppinge van die evangelis nie, maar is afkomstig uit sy bronne (Luz 1991:73). Die woordeskat en formulêre uitdrukkings wat Matteus by Markus en $\mathrm{Q}$ oorgeneem het, dra egter wel teologiese gewig. Matteus neem die teologiese gedagtes van sy bronne - insluitende formules - oor en bou dit verder uit (Luz 1991:74). Ons het reeds daarop gewys dat Lohr die gebruik van die formule 'Seun van die Mens', soos dit binne die Matteusevangelie figureer, teen hierdie agtergrond bespreek het. Luz bring egter 'n ander perspektief op hierdie 'formule' na vore wanneer hy in ag neem dat Matteus hierdie titel vanuit $Q$ oorgeneem het. In $\mathrm{Q}$ word die 'Seun van die Mens'-titel gebruik in verband met die waarskuwing van die toekomstige oordeel by die paroesie (Luz 1991:74). Matteus neem hierdie tema by $\mathrm{Q}$ oor en sou dus kan veronderstel dat sy lesers bewus was van die konnotasie wat die titel 'Seun van die Mens' met die oordeelstema het. Sou dit 'ou kennis' vir die Matteuslesers/-hoorders gewees het? 'n Verdere ooreenstemming tussen Matteus en $Q$ in hierdie verband is die feit dat albei praat van die 'toekomstige oordeelsfunksie van die Seun van die Mens'. Dit is opvallend dat Matteus vier nuwe Seun van die Menslogia formuleer, te wete in Matteus 13:41; 16:28; 24:30; 25:31 (Luz 1991:74). Die gebruik van hierdie titel in Matteus en $Q$ word albei ook in verband gebring met die konflik met Israel (Luz 1991:74): 'For Matthew, the judgment on Israel is just as central, but he speaks about it differently. Many a $Q$ minatory saying against Israel becomes with him a threat which is directed at the church' (Luz 1991:75). Deur gebruik te maak van bekende formules en temas dra Matteus 'n nuwe tema aan sy gehoor oor, 'n tema wat met ander woorde relevant vir sy gehoor is.

'n Soortgelyke argument kan ten opsigte van Matteus se gebruikmaking van die Markusevangelie gevoer word. Matteus neem in die tweede deel van sy evangelie die 
narratiewe struktuur van die Evangelie van Markus volgens Luz getrou oor. Luz (1991:75) stel dit soos volg: '... Matthew ... is literally a new conception of the Gospel of Mark ...' Van Aarde (1994:xvii) formuleer dieselfde saak soos volg:

The spoken language has the inherent potential of being delivered in a pluriform and therefore polysemantic way. Written language on the contrary, is presented in a unique literary context. If a writer wishes to express the message in a different way at another time, he or she can use the same material to write a different text. And this is exactly what Matthew did with the Markan gospel. By retelling the Gospel of Mark and, in the process, taking over, omitting, adapting or expanding the material, Matthew wrote his own 'theology'.

In beide die Matteus- en Markusevangelie kom onder andere die volgende voor (kyk Luz 1991:75):

* die titel 'Seun van God' is deurslaggewend;

* die Jesus-verhaal dien as transparant vir die situasie van die gehoor van die evangelie;

* $\mu \alpha \theta \eta \tau \alpha i$ en $\dot{\alpha} \kappa o \lambda o v \theta \varepsilon \dot{\omega} \omega$ is sleutelbegrippe wat in die geskiedenis van Jesus en vir die gehoor se eie selfverstaan van deurslaggewende betekenis is;

* die wonderverhale is vir beide evangeliste uitdrukking van hulle eie verhouding met Jesus;

* in beide evangelies is die debat met Israel belangrik.

Dit is in die lig van die bogenoemde ooreenkomste duidelik dat Matteus die bekende/ou kennis gebruik om iets nuuts te sê. Daar is nuwe aspekte in sy teologie wat nie in sy bronne voorkom nie, maar wat hy juis kommunikeer deur sy bronne te gebruik: '... not only Matthean language but also Matthean theology is a continuation - distinctive but basically tradition-bound - of the heritage from his fathers' (Luz 1991:76). Matteus gebruik die oordeelstema intern as vermaning aan die kerk as die lesers/hoorders van die evangelie. Verder beklemtoon Matteus die 'evangelie van Christus' in Mark $1: 1$ as die 'evangelie van die koninkryk' - 'n etiese verkondiging volgens Matteus (Luz 1991:76). Luz is egter van mening dat Matteus nie self verantwoordelik was vir 
dié nuwe aspekte nie, maar dat hy eerder gesien moet word as 'an exponent of his community who accepts and sharpens not only his theological 'teachers', but also the language and the thinking of his community' (Luz 1991:76). Matteus se ervaring met sy gemeenskap bepaal dus die teologie van die evangelie. Die gehoor/gemeenskap aan wie Matteus geskryf het, was met ander woorde bekend met Markus en Q. Dit was vir hulle 'ou kennis'. Luz (1991:78) dui aan dat '... behind the Gospel of Matthew, Jewish-Christian, partly scribal circles become evident, circles which were interested in Q, the Gospel of Mark, other Jesus traditions and the Bible .... [M]atthew is influenced in his language and his theology by his community, he does not write in a vacuum'. Die volgende stelling van Lohr (1961:435) staan in verband met die bogenoemde saak: 'The Evangelist leads and is led. He brings together the materials of the tradition, but the community demands that he adjust them to the traditional style and structures. They are as familiar with the material as he is himself'.

Uit die ondersoek wat in hierdie afdeling gedoen is, kan myns insiens afgelei word dat die Matteusevangelie as 'n literêre teks mondelinge reste vertoon.

\section{GEVOLGTREKKING}

In hierdie ondersoek het ek beoog om na aanleiding van die kenmerke van die kultuur van oraliteit aan te toon of die Matteusevangelie 'n literêre teks met orale reste is. Die vraag is in afdeling een gestel of dit sinvol sou wees om die Matteusevangelie in die lig van die kultuur van oraliteit te bestudeer.

In afdeling twee is aangetoon dat die oraliteitsnavorsing by die formgeschichtliche ondersoek aansluit en wel in dié sin dat die ondersoek na die kultuur van oraliteit vanuit 'n ander hoek die mondelinge voorgeskiedenis van literêre tekste, soos Nuwe-Testamentiese tekste, ondersoek. In hierdie bespreking is aangesluit by die insigte van Gerd Theissen wat die spesifieke historiese situasie - die sosiale en politieke konteks waarin tradisies oorgelewer en geskrifte tot stand gekom het, wil vasstel.

In afdeling drie is die hedendaagse tendense in die oraliteitsnavorsing ondersoek. Daar is tot die gevolgtrekking gekom dat daar in 'n orale kultuur gekommunikeer word deur van orale tegnieke gebruik te maak, waaronder veral formules en temas. Formules dra nie op sigself betekenis nie, maar verwys na die alreeds bekende. So word kontinuiteit met die verlede gehandhaaf. Die implikasie hiervan is dat nuwe kennis oorgedra kan word deur die gebruik van formules wat met behulp van reeds bekende temas iets nuuts in 'n nuwe konteks kan oordra. Die tegniek van herhaling staan in mondelinge kulture op die voorgrond en struktuur word aan 'n voordrag verleen deur die herhaling van formules. 'n Herhalende formulêre styl is hiervolgens die mees uitstaande kenmerk van 'n kultuur van oraliteit. 
In afdeling vier is die Matteusevangelie na aanleiding van die werke van Charles Lohr, Daniel Patte en Ulrich Luz ondersoek. Na afloop van die studie het ek tot die gevolgtrekking gekom dat hierdie ondersoek die belangrikheid van die beginsel dat antieke skrywers deur middel van die bekende iets nuuts aan hulle hoorders kommunikeer, onderstreep. Aangesien die mondelinge milieu by uitstek gekenmerk word aan die herhaling van formules om temas uit te bou, is hierdie teorie veral toepaslik op mondelinge kulture. Hierdie studie het dus ten doel om die deur te open vir 'n verdere ondersoek na die Evangelie van Matteus aan die hand van die volgende hipotese: 'n outeur gebruik die ou kennis van sy gehoor in verband met formules en temas om 'n nuwe tema (volgens die definisie van Patte) oor te dra. Die Matteusevangelie kan sonder twyfel as illustrasiemateriaal vir hierdie ondersoek dien, vanweë die hoë frekwensie van formules wat in dié evangelie voorkom. Luz (1991:36) se uitspraak is derhalwe behartenswaardig: 'The Matthean language is highly formulaic'.

\section{Literatuurverwysings}

Achtemeier, P J 1990. Omne verbum sonat: The New Testament and the oral environment of late Western antiquity. JBL109, 3-27.

Botha, P J J 1989. Die dissipels in die Markusevangelie. DD-proefskrif, Universiteit van Pretoria.

1990a. The task of understanding the Gospel traditions: Werner Kelber's contribution to New Testament research. HTS 46, 47-70.

1990b. Mute manuscripts: analysing a neglected aspect of ancient communication. Theologia Evangelica 23/3, 35-47.

1991. Mark's story as oral traditional literature: Rethinking the transmission of some traditions about Jesus. HTS 47, 304-331.

Bultmann, R 1963. The history of the synoptic tradition. Oxford: Basil Blackwell.

Crossan, J D 1993. The oral tradition: Remembering the words. Unpublished paper, Westar Institute's Jesus Seminar, Santa Rosa (CA), USA.

Funk, R W 1992. The oral repertoire: Quoted speech, gist, cliches, and lists. Unpublished paper, Westar Institute's Jesus Seminar, Santa Rosa (CA), USA.

Gilliard, F D 1993. More silent reading in antiquity: Non omne verbum sonabat. JBL 112, 689-694.

Hahn, F 1985. Zur Formgeschichte des Evangeliums. Darmstadt: Wissenschaftliche Buchgesellschaft. (Wege der Forschung 81.)

Halverson, J 1994. Oral and written Gospel: A critique of Werner Kelber. NTS 40, 180-195. 
Harris, W V 1991. Ancient literacy. Harvard: University Press.

Horsley, R, Burnett, F W \& Phillips, G A 1992. Helmut Koester: Ancient christian Gospels; Gerd Theissen: The Gospels in context. Religious Studies Review 18, 290-295.

Kelber, W H 1980. Mark and oral tradition. Semeia 16, 7-55.

1983. The oral and the written Gospel: The hermeneutics of speaking and writing in the synoptic tradition, Mark, Paul, and $Q$. Philadelphia: Fortress.

Lohr, C H 1961. Oral techniques in the Gospel of Matthew. CBQ 23, 403-435.

Lord, A B 1960. The singer of tales. Harvard: University Press.

Loubser, J A 1993. The oral Christ of Shembe: Believing in Jesus in oral and literate societies. Scriptura 12,70-80.

Luz, U 1990. Matthew 1-7: A commentary. Edinburgh: T\&T Clark.

Mazamiza, W [1992]. Rereading the Bible in the Black Church: Towards a hermeneutic of orality and literacy. Unpublished paper, Studiorum Novi Testamenti Societas, Madrid, Spain.

Patte, D 1987. The gospel according to Matthew. Philadelphia: Fortress Press.

Tannen, D 1982. Spoken and written language: Exploring orality and literacy. Norwood: Ablex.

Theissen, G 1991. The Gospels in context: Social and political history in the Synoptic tradition. Minneapolis: Fortress.

Van Aarde, A G 1984. Eksegetiese metodeleer: Die historiese kritiek en inleiding tot die eksegese van die sinoptiese evangelies. Ongepubliseerde studiegids, Universiteit van Pretoria.

1994. God-with-us: The dominant perspective in Matthew's story, and other essays. Pretoria: University of Pretoria. (HTS Suppl 5.)

Vorster, W S 1987. Rudolf Bultmann as historikus. HTS 43, 138-161.

Zindler, F R 1992. The oracular origin of the Jesus oral tradition. Unpublished paper, Westar Institute's Jesus Seminar, Rutgers University (NJ). 